S. Zaichenko, Prof. Dr., ORCID 0000-0002-8446-5408

S. Shevchuk, Prof. Dr., ORCID 0000-0002-7517-0501

A. Halem, master, ORCID 0000-0002-0593-326X

National Technical University of Ukraine «Igor Sikorsky Kyiv Polytechnic Institute»

\title{
IMPROVING THE ENERGY EFFICIENCY OF AN AUTONOMOUS SOURCE OF ELECTRIC ENERGY BY REGULATING THE GAS DISTRIBUTION OF AN INTERNAL COMBUSTION ENGINE
}

The use of generators with inverters allows, depending on the load of the network, to regulate the speed of the internal combustion engine, thereby reducing fuel consumption and increasing the overall efficiency of the system as a whole. However, it should be noted that the optimal operation of the internal combustion engine is possible at a certain engine speed. A decrease in the engine speed leads to a deterioration in the filling of the fuelair mixture and the exhaust of the engine, accompanied by an intake of exhaust gases into the intake manifold and the ejection of part of the combustible mixture into the exhaust pipe. The paper presents the general concept of creating a control system for an autonomous power source based on an internal combustion engine and an inverter. The expediency of adjusting the opening and closing angles of an internal combustion engine that works as a source of mechanical energy of an autonomous source of electrical energy is proved. The use of this system allows to reduce unit costs by 2 times when generating electric energy. Based on the gas distribution diagram of the internal combustion engine, the dependence of the change in the opening and closing angles of the intake and exhaust valves on the power of an autonomous energy source is proposed.

Key words: autonomous energy source, energy conversion efficiency, gas distribution system, electromagnetic valve

\section{Introduction}

In most cases, ensuring reliable energy supply in the event of an external grid failure use autonomous sources of energy based on internal combustion engines. The volume of electricity production in 2017 by autonomous stations is within 6.5 million $\mathrm{kWh}$, with a total production volume of about $5 \%$ [1]. The main feature of autonomous energy sources is the kind of fuel used to generate thermal energy from chemical: gasoline, diesel, gas. However, in general, the design and principle of the chemical energy to mechanical converter itself remains similar in basic terms: two- or four-stroke cycle, crank mechanism, piston, cylinder, etc. Second in importance for autonomous energy sources based on an internal combustion engine is the principle of converting mechanical energy into electrical energy. There are two main features of autonomous power sources: no inverters with inverters. The use of generators with inverters allow, depending on the load of the network, to adjust the speed of the internal combustion engine. This will reduce fuel consumption and increase the overall efficiency of the system as a whole. So using this scheme allows to save more than half of the total amount of fuel [2-4].

However, it should be noted that the optimum performance of the internal combustion engine is possible at a certain engine speed [4]. This is evident from the internal combustion engine efficiency diagrams that have a domed shape with a maximum at 2500-3500 rpm depending on the design. The decrease in engine speed causes the fuel-air mixture to fill and the engine exhaust. This process is followed by the intake of exhaust gases into the intake manifold and the ejection of some of the combustible mixture into the exhaust pipe. Energy losses in the event of these effects can reach up to $20 \%$, which significantly reduces the effect of using the inverter when generating electricity.

Among a wide range of standalone generators, the authors have focused on generating installations based on a single-cylinder gasoline four stroke internal combustion engine with a volume of engine $200 \mathrm{sm}^{2}$. The choice of the object of study was determined from the analysis of the existing demand of generators and own practice, which is due to the relatively low cost of the generating unit, compared to diesel generators and the minimum required power for the operation of powerful household appliances, which averages $2.2 \mathrm{~kW}$. It should be noted that synchronous generators without inverter remain the most common autonomous source of electrical energy. The peculiarity of the generator without the inverter is the constant speed of the crankshaft of the engine without the ability to adjust the power.

In view of the above, to increase the energy efficiency of an autonomous power source inverter based on an internal combustion engine by regulating the gas distribution mechanism is an urgent scientific task.

The purpose and objectives of the study

The purpose of this study is to determine the algorithm of operation and parameters of the control system of an autonomous source of electric energy with an internal combustion engine by regulating the gas distribution of the internal combustion engine in order to increase the overall efficiency.

(C) С.В. Зайченко, С.П. Шевчук, А. Халем, 2019 
In order to achieve this goal, the following tasks were solved in the work:

- Development of control scheme for autonomous power supply based on internal combustion engine and inverter.

- Investigation of the change of energy efficiency parameters of the engine-generator-inverter system from the load level.

- Creating recommendations for adjusting the parameters and methods of implementing the control of the internal combustion engine with mini power autonomous power supply.

\section{Material and results of the study}

In the analysis of the design of autonomous energy sources based on the internal combustion engine, it should be noted the main components: engine, generator, inverter (Fig. 1).

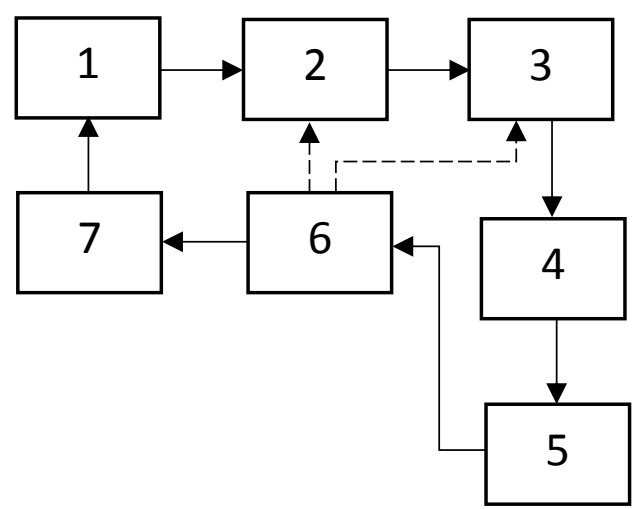

Fig. 1 - Control scheme for autonomous power source based on internal combustion engine and inverter:

1 - internal combustion engine; 2 - generator; 3 - inverter; 4 - wattmeter; 5 - analog-to-digital converter; 6 microcontroller; 7 - electromagnet driver

A wattmeter is used to control the power level consumed by the energy meter - 4, which is connected to the microcontroller - 5 via an analog - to - digital converter. For more precise control of the parameters of the elements of a standalone generator, it is possible to use channels that connect the microcontroller to the generator and inverter.

In determining the optimal control effects on the constituent elements of the system, consider the need to establish the features of their work under different load separately.

In the system under study, the internal combustion engine is the least energy efficient element. The efficiency of four-stroke internal combustion engines at optimum speed and load is within $45 \%(50 \%)$ of diesel engines and $39 \%$ for gasoline. At the same time (Fig. 2), analyzing the graphs [5], the changes in the efficiency of power from the ICE should be noted about a significant (up to 30\%) drop with a sharp increase in specific fuel consumption (up to $500 \%)[6,7]$.
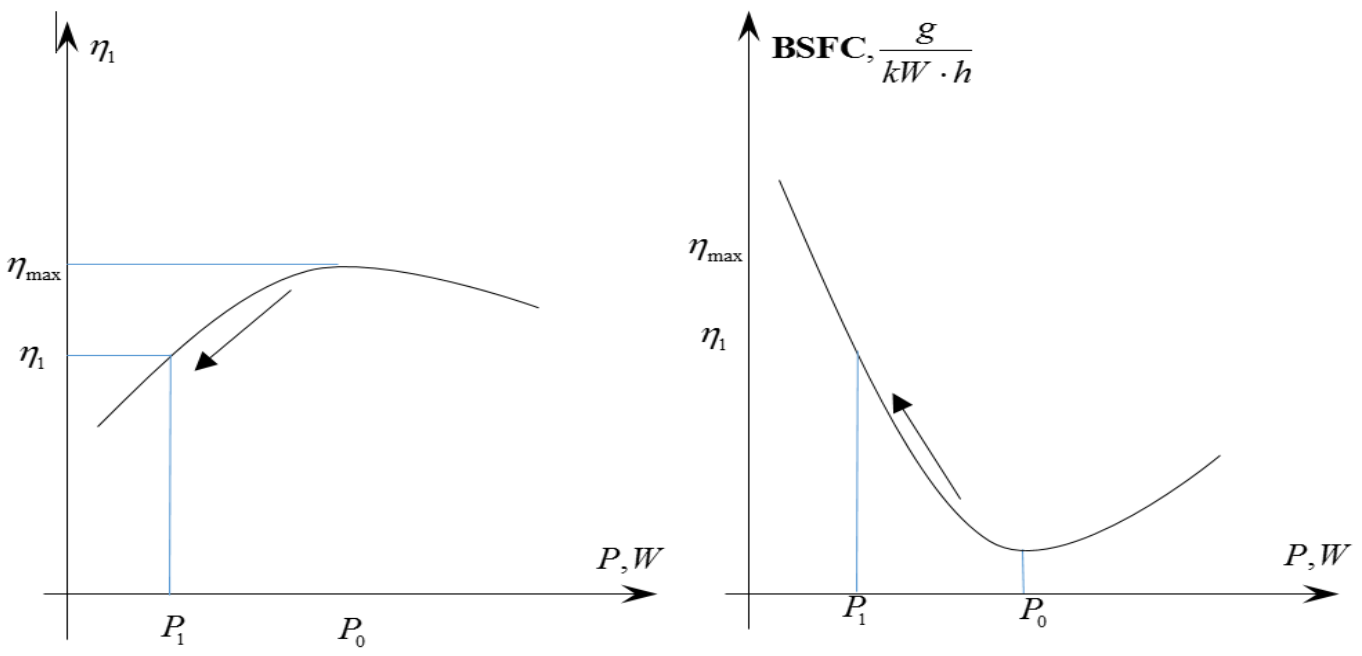

Fig. 2 - Charts of change of efficiency and BSFS

The cause of this phenomenon is a number of negative phenomena that accompany the process of reducing the engine speed. The main concern is the deterioration of the gas filling of the cylinder, the reduction of turbulence with the discharge of part of the charge from the cylinder into the inlet system during the delay of closing the inlet 
valve after the NMT. Prevention of this phenomenon is possible by regulating the time and height of valve opening, namely narrowing cycles with late opening and early closing of valves without overlapping [8].

Figure 3a shows a typical diagram of the gas phase distribution of the internal combustion engine at rated speed. The diagram shows the overlap of the corners of the outlet and inlet zones by the magnitude of the inlet and outlet valves. The value of the angles is selected from the condition of obtaining maximum torque and efficiency of the engine [9]. One of the possible options for avoiding these negative phenomena is to minimize the angles of opening of the inlet and closing of the exhaust valves (Fig. 2b) while reducing engine speed.

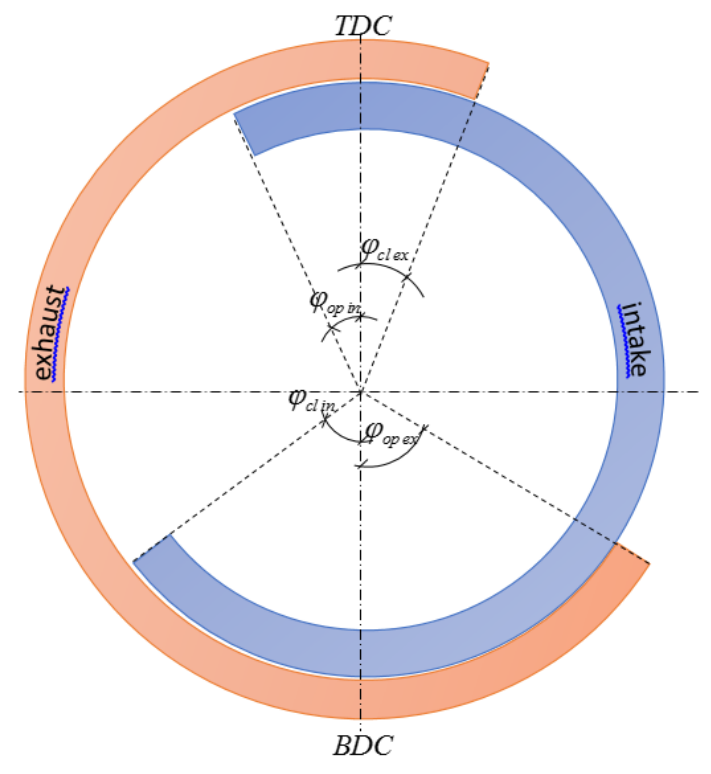

a

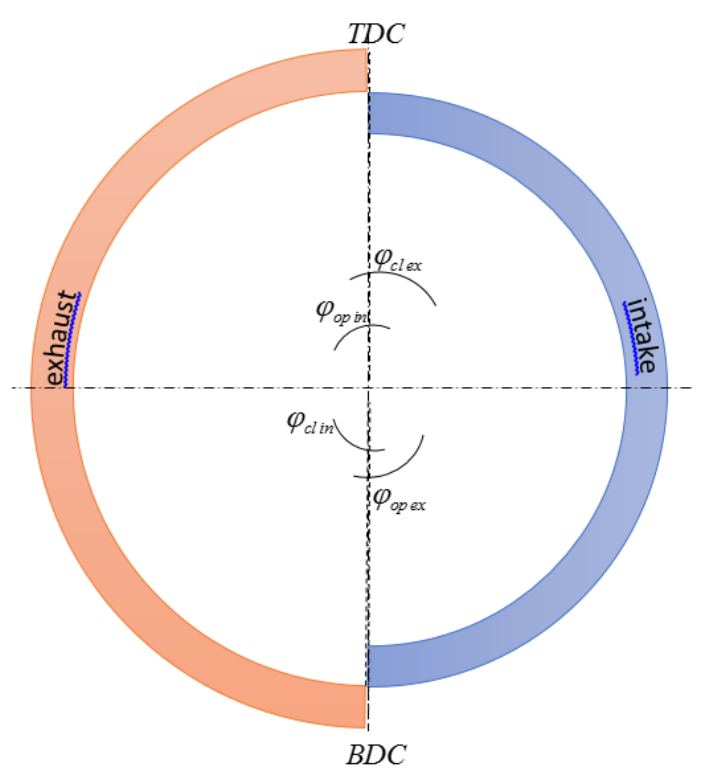

6

Fig. 3 - ICE phase diagrams: a - at nominal speed; $b$ - at minimum revolutions

A system of linear equations is proposed to set the angles of opening and closing of the inlet valves from the power level $P$ :

$$
\begin{gathered}
\varphi_{\text {opin }}(P)=\frac{\varphi_{\text {opin }}}{P_{0}-P_{1}}\left(P-P_{1}\right) \\
\varphi_{\text {opex }}(P)=\frac{\varphi_{\text {opex }}}{P_{0}-P_{1}}\left(P-P_{1}\right) \\
\varphi_{\text {clin }}(P)=\frac{\varphi_{\text {clin }}}{P_{0}-P_{1}}\left(P-P_{1}\right) \\
\varphi_{\text {clex }}(P)=\frac{\varphi_{\text {clex }}}{P_{0}-P_{1}}\left(P-P_{1}\right)
\end{gathered}
$$

The implementation of the proposed method of controlling the gas distribution of the internal combustion engine is possible through the use of special actuators of the gas distribution mechanism. Mechanical, hydromechanical and electric actuators are common. Moreover, among these types of actuators, high-performance twilight actuators are electromagnetically actuated actuators due to the slow movement of the valve with a cam and hydraulic actuator [10, 11].

We define the main parameters of the process of motion of the exhaust valve of the engine under the action of an electromagnet (Fig. 4). When moving the valve 2 down the electromagnet 1 must develop a force $F_{e m}$ equal to the total resistance from the action $F_{1}$ of the spring 3, from the action of gases $F_{2}$ and forces of inertia. In the general case, the equation of motion of the valve is as follows:

$$
m_{v} \frac{d^{2} z}{d t^{2}}+\vec{F}_{1}+\vec{F}_{2}+\vec{F}_{e m}=0
$$

where $m_{v}$ - the mass of the valve with the anchor. 


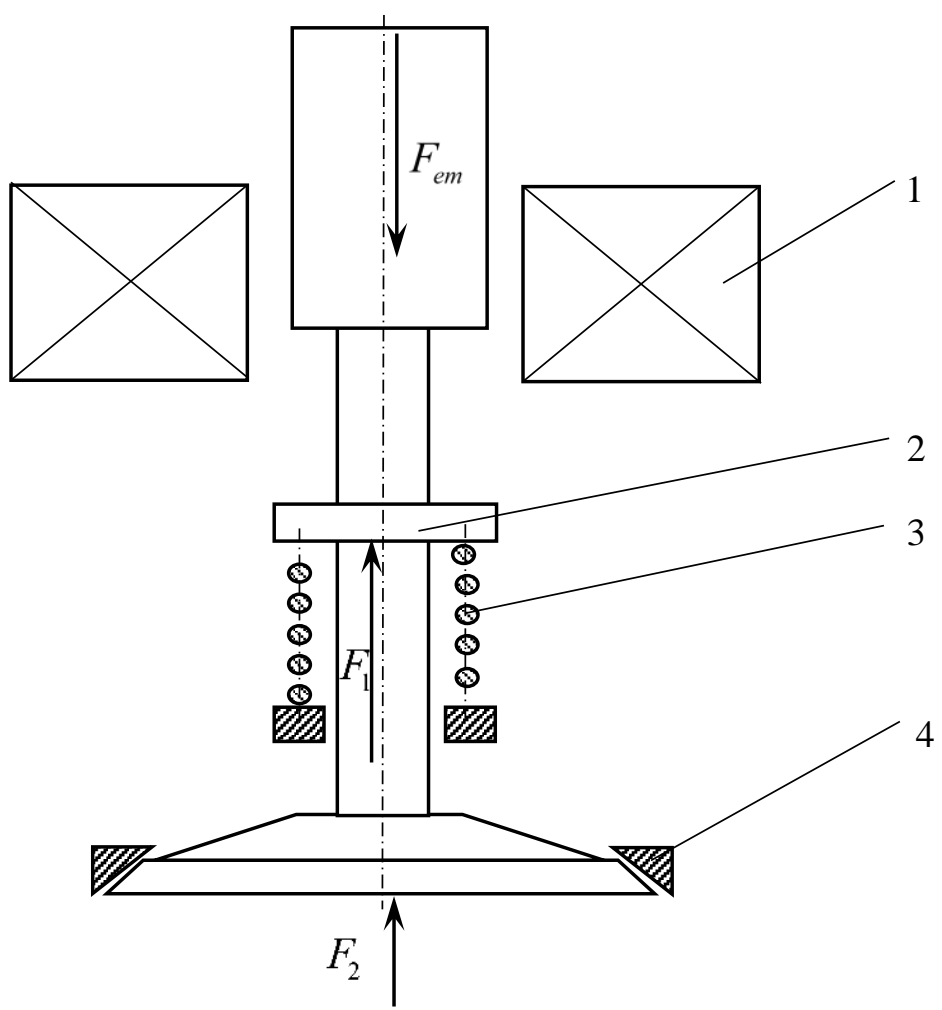

Fig. 4 Scheme of electromagnetic forces exhaust valve: 1 - electromagnet; 2 - valve; 3 - spring; 4 - valve seat

The force of resistance from the action of the spring:

$$
F_{1}=F_{1}^{\prime}+c z
$$

$F_{1}^{\prime}$ - previous compression force of the spring;

$\mathrm{c}-$ spring stiffness.

The force of resistance from the action of compressed gases depends on the moment and height of the valve opening. The value of the initial pressure corresponds to the end of the expansion cycle, for the case of a gasoline engine is $p_{1}=0,3-0,4 M P a$. Further movement of the valve is accompanied by a rapid drop in pressure to $p_{2}=0,03-0,04 M P a$. The valve closes when it is rarefied $p^{\prime}=0,035-0,045 M P a$

As noted above, the main advantage of the electromagnetic drive of the engine's gas distribution mechanism is the speed. To determine the required force of the electromagnet in the implementation of uniformly accelerated valve movement, set the parameters of the tachogram of motion (fig. 4). Total valve travel time:

$$
t_{0}=\frac{\varphi_{\text {opex }}+\varphi_{\text {clex }}+\pi / 2}{\omega}
$$

$\omega$ - the speed of rotation of the crankshaft.

The opening and closing times of the valve in modern cam-driven motors depend on the specified cam profile and in some cases may be equal to the total valve travel time. Assume a fixed value of angles $\varphi_{\text {opex }}^{\prime}, \varphi_{c l e x}^{\prime}$ in which the exhaust valve will fully open to height $h$. Valve opening and closing time:

$$
t_{1}=\frac{\varphi_{\text {opex }}^{\prime}}{\omega} ; \quad t_{2}=\frac{\varphi_{c l e x}^{\prime}}{\omega} .
$$

Accordingly, the acceleration:

$$
a_{1}= \pm 4 h\left(\frac{\omega}{\varphi_{\text {opex }}^{\prime}}\right)^{2} \quad a_{1}=\mp 4 h\left(\frac{\omega}{\varphi_{\text {clex }}^{\prime}}\right)^{2} .
$$

Given the said force of resistance to the action of compressed gases and rarefaction: 


$$
F_{2}=\frac{\pi D^{2}}{4} \frac{\left(p_{1}-p_{2}\right)}{t_{1}} t ; \quad F_{2}^{\prime}=\frac{\pi D^{2}}{4} p^{\prime} .
$$

Fig. 4 - Tachograph of movement of the engine exhaust valve at the action of the electromagnet

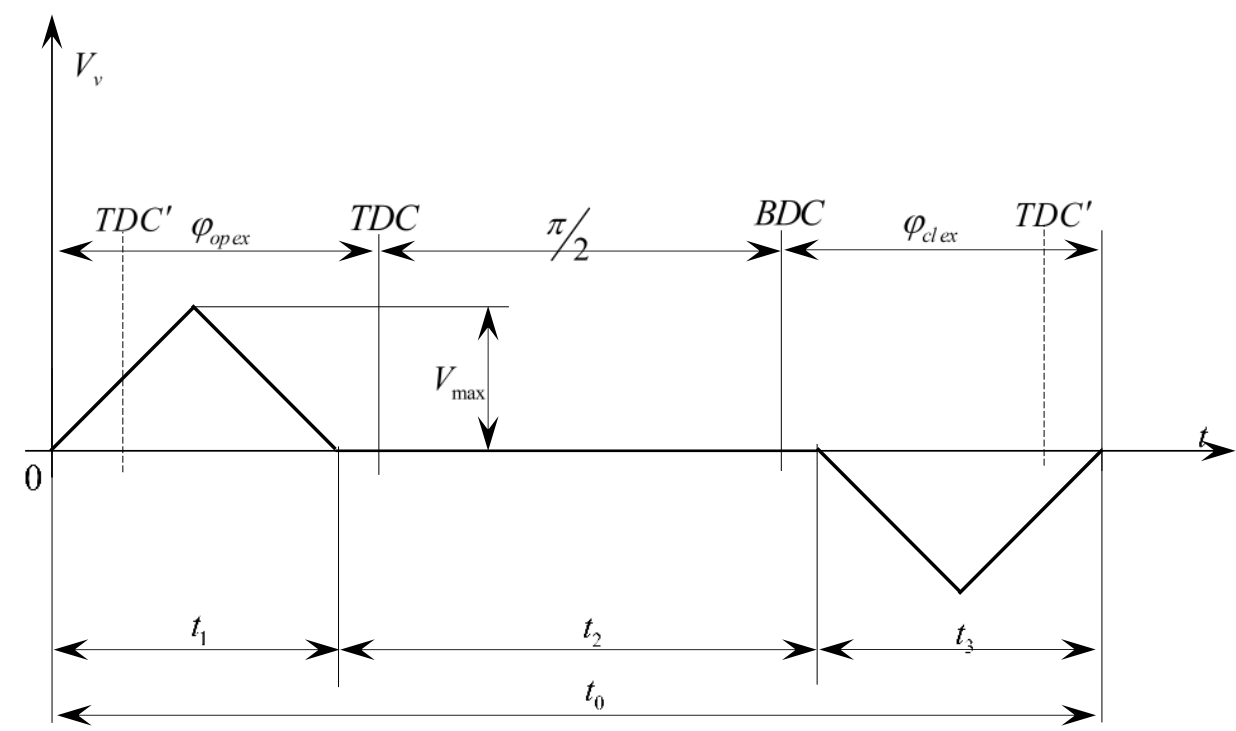

Expressed from equation (5) with known components, we obtain a system of equations to determine the force of action of the solenoid valve in different parts of the tachogram:

$$
\begin{gathered}
\vec{F}_{c m}(t)=m_{v} 4 h\left(\frac{\omega}{\varphi_{o p e x}^{\prime}}\right)^{2}+F_{1}^{\prime}+c \frac{4 h\left(\frac{\omega}{\varphi_{o p e x}^{\prime}}\right)^{2} t^{2}}{2}+\frac{\pi D^{2}}{4}\left(p_{1}-\frac{\left(p_{1}-p_{2}\right)}{t_{1}} t\right), t \in\left[0 ; \frac{t_{1}}{2}\right) ; \\
\vec{F}_{e m}(t)=-m_{v} 4 h\left(\frac{\omega}{\varphi_{\text {opex }}^{\prime}}\right)^{2}+F_{1}^{\prime}+c\left(\frac{h}{2}+\frac{\left.4 h\left(\frac{\omega}{\varphi_{\text {opex }}^{\prime}}\right)^{2}\left(t-\frac{t_{1}}{2}\right)^{2}\right)}{2}+\frac{\pi D^{2}}{4}\left(p_{1}-\frac{\left(p_{1}-p_{2}\right)}{t_{1}}\left(t-\frac{t_{1}}{2}\right), t \in\left[\frac{t_{1}}{2} ; t_{1}\right) ;\right.\right. \\
\vec{F}_{e m}(t)=-m_{v} 4 h\left(\frac{\omega}{\varphi_{c l e x}^{\prime}}\right)^{2}+F_{1}^{\prime}+c\left(h-\frac{4 h\left(\frac{\omega}{\varphi_{c l e x}^{\prime}}\right)^{2}\left(t-\left(t_{0}+t_{2}\right)\right)^{2}}{2}\right)-\frac{\pi D^{2}}{4} p^{\prime}, t \in\left[t_{0}-t_{2} ; t_{0}-\frac{t_{2}}{2}\right) ; \\
\vec{F}_{e m}(t)=m_{v} 4 h\left(\frac{\omega}{\varphi_{c l e x}^{\prime}}\right)^{2}+F_{1}^{\prime}+c\left(h-\frac{\vec{F}_{e m}(t)=F_{1}^{\prime}+c h t}{4 h\left(\frac{\omega}{\varphi_{c l e x}^{\prime}}\right)^{2}\left(\frac{t_{2}}{2}\right)^{2}}-\frac{\left.4 h\left(\frac{\omega}{\varphi_{c l e x}^{\prime}}\right)^{2}\left(t-\left(t_{0}-\frac{t_{2}}{2}\right)\right)^{2}\right)}{2} t_{0}-\frac{\pi D^{2}}{4} p^{\prime}, t \in\left[t_{0}-\frac{t_{2}}{2} ; t_{0}\right] .\right.
\end{gathered}
$$

From the analysis of equations (11-15) and the tachogram (fig. 4) it is possible to conclude that the greatest effort the electromagnet should develop at maximum revolutions at the beginning of the section $t \in\left[0 ; t_{1}^{t} / 2\right)$, and the maximum power at the end of the site $t \in\left[0 ; t_{1} / 2\right)$ where the valve develops maximum speed:

$$
V_{\max }=\frac{2 h \omega}{\varphi_{\text {opex }}^{\prime}} .
$$

For selection, set the maximum force and power of the electromagnet for the most common type of internal combustion engine used for autonomous energy sources: Honda GX-200. The parameters required for the calculation are shown in table 1. 
Table 1 - Parameters of the Honda GX-200 gas distribution system

\begin{tabular}{|c|l|l|l|}
\hline № parameter & Parameter & Unit & Value \\
\hline 1 & Weight of the valve & $\mathrm{kg}$ & 0,022 \\
\hline 2 & Valve opening height & $\mathrm{m}$ & 0,006 \\
\hline 3 & Crankshaft rotation speed & $\mathrm{c}^{-1}$ & 402 \\
\hline 4 & Valve opening angle & $\mathrm{rad}$ & 0,35 \\
\hline 5 & Previous compression force of spring & $\mathrm{H}$ & 100 \\
\hline 6 & Spring stiffness & $\mathrm{H} / \mathrm{m}$ & 10000 \\
\hline 7 & Piston head diameter & $\mathrm{m}$ & 0,027 \\
\hline 8 & Initial pressure & $\mathrm{Pa}$ & 300000 \\
\hline 9 & The final pressure & $\mathrm{Pa}$ & 30000 \\
\hline
\end{tabular}

The force of the electromagnet at the beginning of the movement:

$$
\vec{F}_{e m}(0)=1,073 \cdot 10^{3} \mathrm{~N}
$$

The power and power of the electromagnet at the end of acceleration:

$$
\vec{F}_{e m}\left(\frac{t_{1}}{2}\right)=991 \mathrm{~N} ; N_{e m}=1,362 \cdot 10^{4} \mathrm{~W} .
$$

It should be noted that a magnet with such parameters is quite large and requires an additional source of energy. However, the amount of energy expended in the valve control process is less than $1 \%$ of engine power. This allows the process to be implemented through an autonomous power source with energy storage.

\section{Conclusions}

1. The general concept of creation of control system of autonomous power supply on the basis of internal combustion engine and inverter is presented in the work. The feasibility of adjusting the angles of opening and closing of the internal combustion engine operating as a source of mechanical energy of an autonomous source of electricity has been proved. Application of this system allows to reduce specific costs by 2 times when generating electricity.

2. The diagram of the phase gas distribution of the internal combustion engine (Fig. 3, a) for the conditions of minimum energy generation is proposed. On the basis of the diagram of the phase gas distribution of the internal combustion engine, the dependence of the change of the angles of opening and closing of the inlet and outlet valves on the capacity of the autonomous energy source (1-4) is proposed.

3. The equation of dynamics of motion in the valve with electromagnetic actuator is established. On the basis of the equation of motion dynamics, the force of the magnet is determined in the implementation of evenly accelerated valve movement. From the analysis of equations (11-15) and the tachogram (fig. 4) it is found that the greatest effort is the electromagnet develops at maximum revolutions $1,073 \cdot 10^{3} \mathrm{~N}$ at the beginning of the section, and the maximum power $1,362 \cdot 10^{4} \mathrm{~W}$ at the end of the section where the valve develops the maximum speed.

\section{Bibliography}

1. Intelligent electric power systems: elements and modes: Under the general. ed. Acad. NAS of Ukraine A.V. Kirilenko / Institute of Electrodynamics of NAS of Ukraine. - K .: Institute of Electrodynamics of the NAS of Ukraine, 2014 .-- 408 p.

2. Galiullin R. R. On the issue of regulating the rotational speed of the crankshaft of a diesel autonomous power plant of low power // Vestnik BGAU. - 2012 .-- S. 37-40.

3. Bashirov R.M. Fundamentals of the theory and calculation of automotive engines. Ufa: BGAU, 2008. 304 p.

4. Galiullin R.R., Gaysin E.M. Regulation of diesel engines by skipping fuel supplies // Mechanization and Electrification of Agriculture, 2005. No. 11. P. 30-31.

5. Kozlov A.N., Khudyakova G.I., Svishchev D.A. Efficiency of the internal combustion engine using synthesis gas // Energy and Resource Saving. Power supply. Unconventional and renewable energy sources. Yekaterinburg, 2016. - 2016. - S. 548-552.

6. Khvatov O.S., Daryenkov A. B., Samoyavchev I. S. Fuel efficiency of a single power plant of an autonomous facility based on an internal combustion engine of variable rotational speed // Operation of sea transport. - 2013. - No. 1 .-- S. 71.

7. Alekseenko V. A., Yurov B. B., Ostapenko V. V. Load characteristic of the carburetor engine // Collection of scientific papers Sworld. - 2014. - T. 2. - No. 2. - S. 29-31.

8. Akhromeshin A. V. Modern gas exchange control systems for internal combustion engines (review) // Bulletin of Tula State University. Technical science. - 2008. - No. 3.- S. 151-158. 
9. Zakharov L. A., Khrunkov S. N., Limonov A. K. Methods for choosing the rational technical characteristics of the gas distribution mechanism of a reciprocating internal combustion engine // Transactions of NGTU im. RE Alekseeva. - 2010. - No. 4. - S. 181-189.

10. Zakharov L. A., Khrunkov S. N., Limonov A. K. The methodology for choosing the rational technical characteristics of the gas distribution mechanism of a reciprocating internal combustion engine // Transactions of NGTU im. RE Alekseeva. - 2010. - No. 4. - S. 96-105.

11. Akhromeshin A. V. Modern gas exchange control systems for internal combustion engines (review) // Bulletin of Tula State University. Technical science. - 2008. - No. 3. - S. 151-158.

УДК 621.43

С.В. Зайченко, проф. Д-р, ORCID 0000-0002-8446-5408 С.П. Шевчук, проф. Д-р, ORCID 0000-0002-7517-0501 А. Халем, магистр, ORCID 0000-0002-0593-326X

Национальный технический университет Украины «Киевский политехнический институт имени Игоря Сикорского»

\title{
ПОВЫШЕНИЕ ЭНЕРГОЭФФЕКТИВНОСТИ АВТОНОМНОГО ИСТОЧНИКА ЭЛЕКТРИЧЕСКОЙ ЭНЕРГИИ ПУТЕМ РЕГУЛИРОВАНИЯ ГАЗОРАСПРЕДЕЛЕНИЯ ДВИГАТЕЛЯ ВНУТРЕННЕГО СГОРАНИЯ
}

\begin{abstract}
Использование генераторов с инверторами позволяют в зависимости от нагрузки сети регулировать частоту вращения двигателя внутреннего сгорания, таким образом уменьшать расход топлива и повысить общчй коэффициент полезного действия системь в целом. Однако следует отметить, что оптимальная работа двигателя внутреннего сгорания возможна при определенной частоте вращения двигателя. Уменьшение частоть вращения двигателя приводит к ухудшению наполнения топливо-воздушной смесью и выпуска отработавших газов двигателя, сопровождаюшееся впуском выхлопных газов во впускной коллектор и выброса части горючей смеси в выхлопную трубу. В работе представлена общая конщепщия создания системы управления автономным источником питания на базе двигателя внутреннего сгорания и инвертора. Доказана целесообразность регулирования углов открытия и закрытия двигателя внутреннего сгорания который работает, как источник механической энергии автономного источника электрической энергии. Применение данной системы позволяет уменьшить удельные затраты в 2 раза при генерации электрической энергии. На основе диаграммы фазового газораспределения ДВС предложено зависимость изменения углов открытия и закрытия впускного и выпускного клапанов от мощности автономного источника энергии.

Ключевые слова: автономный источник энергии, коэффициент полезного действия, система газораспределения, электромагнитный клапан
\end{abstract}

УДК 621.43

С.В. Зайченко, проф. Д-р, ORCID 0000-0002-8446-5408 С.П. Шевчук, проф. Д-р, ORCID 0000-0002-7517-0501 А. Халем, магістр, ORCID 0000-0002-0593-326X Національний технічний університет України «Київський політехнічний інститут імені Ігоря Сікорського»

\section{ПІДВИЩЕННЯ ЕНЕРГОЕФЕКТИВНОСТІ АВТОНОМНОГО ДЖЕРЕЛА ЕЛЕКТРИЧНОЇ ЕНЕРГІЇ ШЛЯХОМ РЕГУЛЮВАННЯ ГАЗОРОЗПОДІЛУ ДВИГУНА ВНУТРІШНЬОГО ЗГОРЯННЯ}

\footnotetext{
Використання генераторів з інверторами дозволяють в залежності від навантаження мережі регулювати частоту обертання двигуна внутрішнього згоряння, таким чином зменшувати витрату палива і підвищити загальний коефіцієнт корисної дї системи в цілому. Однак слід зазначити, щзо оптимальна робота двигуна внутрішнього згоряння можлива при певній частоті обертання двигуна. Зменшення частоти обертання двигуна призводить до погіршення наповнення паливо-повітряною сумішшю $і$ випуску
} 
ISSN 1813-5420 (Print). Енергетика: економіка, технологї̈, екологія. 2019. № 3

відпраџьованих газів двигуна, щуо супроводжується впусканням вихлопних газів у впускний колектор і викиду частини горючої суміші в вихлопну трубу. У роботі представлена загальна концепція створення системи управління автономним джерелом живлення на базі двигуна внутрішнього згоряння і інвертора. Доведено доиільність регулювання кутів відкриття $і$ закриття двигуна внутрішнього згоряння який працює, як джерело механічної енергії автономного джерела електричної енергії. Застосування даної системи дозволяє зменшити питомі витрати в 2 рази при генерачії електричної енергії. На основі діаграми фазового газорозподілу ДВС запропоновано залежність зміни кутів відкриття $і$ закриття впускного $і$ випускного клапанів від потужності автономного джерела енергії.

Ключові слова: автономне джерело енергї, коефіцієнт корисної дї, система газорозподілу, електромагнітний клапан

Надійшла 09.10.2019

Received 09.10.2019 